\title{
A Four-Year, Seven-State Reforestation Trial with Eastern Hemlocks (Tsuga canadensis) Resistant to Hemlock Woolly Adelgid (Adelges tsugae)
}

\author{
Ian G. Kinahan ${ }^{1}$, Gabrielle Grandstaff ${ }^{1}$, Alana Russell ${ }^{2}$, Chad M. Rigsby ${ }^{1,3}$, \\ Richard A. Casagrande ${ }^{2}$ and Evan L. Preisser $1, *$ (D) \\ 1 Department of Biological Sciences, The University of Rhode Island, Kingston, RI 02881, USA; \\ ikinahan@uri.edu (I.G.K.); ggrandstaff@my.uri.edu (G.G.); crigsby@bartlett.com (C.M.R.) \\ 2 Department of Plant Sciences and Entomology, The University of Rhode Island, Kingston, RI 02881, USA; \\ alana_russell@uri.edu (A.R.); casa@uri.edu (R.A.C.) \\ 3 Bartlett Tree Research Laboratories, The Morton Arboretum, Lisle, IL 60532, USA \\ * Correspondence: preisser@uri.edu
}

Received: 23 February 2020; Accepted: 9 March 2020; Published: 12 March 2020

check for updates

\begin{abstract}
We conducted over a decade of research into individual eastern hemlock (Tsuga canadensis; hemlock) trees that are potentially resistant to hemlock woolly adelgid (Adelges tsugae; HWA), an invasive xylem-feeding insect that is capable of rapidly killing even mature trees. Following clonal propagation of these individuals, in 2015 we planted size- and age-matched HWA-resistant and HWA-susceptible hemlocks in HWA-infested forest plots in seven states. In 2019, we re-surveyed the plots; $96 \%$ of HWA-resistant hemlocks survived compared to $48 \%$ of susceptible trees. The surviving HWA-resistant trees were also taller, produced more lateral growth, retained more foliage, and supported lower densities of the elongate hemlock scale Fiorinia externa, another invasive hemlock pest, than the surviving HWA-susceptible trees. Our results suggest that HWA management may benefit from additional research exploring the identification, characterization, and use of HWA-resistant eastern hemlocks in future reforestation efforts.
\end{abstract}

Keywords: eastern hemlock; hemlock woolly adelgid; Fiorinia externa; resistance; reforestation

\section{Introduction}

Although chemical suppression and biological control efforts are often the primary tools for managing non-native forest insects and pathogens (hereafter, 'pests'), research that identifies the potential for pest resistance in host plant populations has played an integral role in many forest pest management programs [1]. Dutch elm disease (Ophiostoma ulmi and Ophiostoma novo-ulmi; hereafter, 'DED'), for instance, is the most destructive pest of shade-trees in the United States [2], having wiped out nearly 100 million American elms (Ulmus americana L.) in both urban and forest populations [3]. Healthy, mature individual American elms persist, however, in DED-devastated forests throughout the eastern USA [2], and research suggests that these trees are less susceptible to the disease [4]. The production and evaluation of clonal propagules from these trees has yielded several DED-tolerant American elm genotypes that are commercially available [4] and currently being used in ecosystem restoration [5]. Similarly, chestnut blight (Cryphonectria parasitica (Murrill) Barr) has rendered the American chestnut (Castanea dentata (Marsh.) Borkh.) functionally extinct throughout most of its range [6]. While biological control has proven relatively unsuccessful in population-level management of this pest [7], research on surviving individual American chestnuts has identified some degree of blight resistance in these trees [8]. In addition to research on genetically-modified individuals, several ongoing breeding programs utilizing backcrossing of lingering American chestnuts with 
blight-resistant Chinese chestnuts (C. mollissima) have produced relatively blight-resistant individuals that are phenotypically indistinguishable from American chestnuts [9]. Preliminary reforestation trials indicate that these blight-resistant American chestnut hybrids may well prove critical in restoring chestnuts to blight-devastated forests of the eastern USA [10].

Research examining host plant resistance is especially important in cases where a pest cannot be effectively controlled by biological control or insecticides [11-13]. One such pest is the hemlock woolly adelgid (Adelges tsugae; hereafter, 'HWA'), a hemipteran accidentally introduced from Japan approximately 70 years ago [14] that has caused the widespread mortality and decline of eastern hemlock (Tsuga canadensis; hemlock) and is now present throughout the eastern USA [15]. While insecticides can protect individual trees or small stands, they must be re-applied periodically and are impractical for forest-level application. Although several HWA biological control agents have been approved for release and others are currently being evaluated, evidence is mixed regarding their effect on forest health [16]. At the same time, there is ample evidence of interspecific variation in hemlock resistance to HWA [17,18]. Chinese hemlock (T. chinensis) has repeatedly been shown to be resistant [19-21], while western hemlock (T. heterophylla) and other Asian hemlock species sustain lower HWA densities [21] and possess foliar terpene profiles that differ substantially from those of the HWA-susceptible hemlock species [18]. Researchers have attempted to take advantage of this variation by crossing both HWA-susceptible hemlock species (T. canadensis and T. caroliniana) with HWA-resistant hemlocks; unfortunately, none of the T. canadensis crosses produced viable offspring [22].

The fact that other Tsuga species possess adelgid resistance suggests that this trait has at least the potential to occur in individual T. canadensis. This argument was supported by work showing that the foliar terpenes (chemicals used by the plant to defend against HWA and other pests) found in several dwarf T. canadensis cultivars differ substantially from those of 'wild' T. canadensis [17]. This work inspired two of us (RC and EP) to explore the potential of variation in HWA resistance within T. canadensis. We created and distributed a pamphlet asking forest managers and other concerned groups for their help in locating and identifying eastern hemlocks that appeared to be HWA-resistant [23]. Qualifying trees had to be mature eastern hemlocks that appeared completely healthy, were located within HWA-devastated hemlock stands, and had not been chemically treated. This effort and additional discussions with HWA researchers led to the identification of a small stand of eastern hemlocks growing within the Walpack Fish and Wildlife Management Area in northern New Jersey, USA [23]. Many trees within this forest (nicknamed the "bulletproof stand" by the NJ Department of Environmental Protection employee who found it) were mature and appeared healthy, with deep green foliage and little to no HWA infestation, despite growing in an HWA-devastated forest where HWA had been present for over 30 years. We evaluated HWA resistance in five of these trees via inoculation of rooted stem cuttings with HWA; after a three-month period, the densities of progrediens on HWA-resistant eastern hemlock propagules were significantly lower than those on HWA-susceptible propagules [23]. Subsequent chemical analyses of foliage samples collected from parent HWA-resistant hemlocks in situ found significantly higher terpene concentrations in their twigs and needles than in the twigs and needles of HWA-susceptible hemlocks growing within a five-mile radius [24]. While these results may have reflected different site conditions, they also reported on repeated analyses of foliage samples from two-year old clonal propagules from the same two tree populations. Although both HWA-resistant and HWA-susceptible plants were grown under identical conditions in an outdoor raised bed, the results found that the HWA-resistant trees had higher concentrations of all 22 measured terpenes in their twigs and needles. The authors suggest that these higher concentrations may provide a potential mechanism for these trees' reduced vulnerability to HWA [24].

We present the results of a four-year, seven-state reforestation trial with clonally-propagated HWA-resistant eastern hemlocks. Resistant and susceptible trees were planted in eight HWA-infested forest plots located in seven northeastern USA states. Four years after their establishment, we assessed the stands for tree survival, growth, and infestation with HWA and the elongate hemlock scale 
Fiorinia externa (hereafter, 'EHS'), a co-occurring invasive insect that also feeds on eastern hemlock [25]. We hypothesized that HWA-resistant eastern hemlocks would have higher survival rates, better growth characteristics, and lower pest densities.

\section{Methods}

\subsection{Source Trees}

All HWA-resistant propagules used in this study were collected from parent trees \#3 and \#4 growing in the "Bulletproof Stand" in the Walpack Fish and Wildlife Management Area in northern New Jersey, USA [23]. Saplings we considered susceptible to HWA were purchased from areas not yet infested with HWA: Evergreen Nursery, Sturgeon Bay, WI (seed source: Upper Peninsula of Michigan, USA,) and Vans Pines Nursery, West Olive, MI (seed source Indiana County, PA, USA). This genetic source of hemlock has been shown to be susceptible in HWA in unrelated experiments (e.g., [26]). In May 2011, both nurseries provided 20-30 cm saplings which were potted into 4 liter nursery containers with Metro Mix 830 growing media (Sungro Horticulture, Agawam, MA, USA) and grown outdoors between greenhouses under a 70\% shade cloth for several years.

\subsection{Greenhouse Propagation}

In January 2011, branch cuttings of $20 \mathrm{~cm}$ terminal growth were taken from parent trees \#3 and \#4 at approximately $3 \mathrm{~m}$ height. Cuttings were placed on ice and immediately transported to the University of Rhode Island (Kingston, RI, USA), where they were stored in a walk-in cooler at $4.4^{\circ} \mathrm{C}$ for no more than $12 \mathrm{hr}$. Cuttings were treated with Dip-N-Grow rooting solution (1\% indole-3-butyric acid, 0.5\% 1-Naphthaleneacetic acid) (Griffin Greenhouse Supplies, Tewksbury, MA, USA), and held in a mist bed [23,24,27]. After six months in the mist bed, rooted plants were potted in 4 liter pots with the same soil mix as controls and placed outdoors between greenhouses under shade cloth next to control plants.

In April 2013, 64 of the potted HWA-resistant saplings and 32 of the susceptible hemlocks were transplanted into an outdoor raised bed $30 \mathrm{~m}$ long by $1 \mathrm{~m}$ wide and $0.5 \mathrm{~m}$ deep in partial shade on the north side of the URI campus greenhouse. The bed was filled with a 1:1 mix of soil and compost and supplemented with soil from a nearby hemlock stand. All saplings were grown in this bed until May 2015 when they were dug and all soil was washed from roots before potting into 15 liter nursery pots with a growing media of composted peanut hulls. The potted plants were then grown under $75 \%$ shade between greenhouses through the summer of 2015.

\subsection{Reforestation Plot Establishment}

In September 2015, all trees used in the field trial were dug, balled, and burlapped. Trees were then treated with dinotefuran (Safari 20 SG) as a bark spray at $\frac{1}{2}$ the lowest label rate $(0.5 \mathrm{tsp} / \mathrm{gal})$, following a series of soap and oil treatments, to ensure that trees were free of living HWA and elongate hemlock scale (Fiorinia externa; EHS) prior to transport and planting. The efficacy of Safari 20 SG has been shown to decline to zero within two years of treatment [28], meaning that the treated trees would have been vulnerable to both pests within 1 to 2 years of planting.

Eight HWA-resistant trees (four propagules from each of parent trees \#3 and \#4) and four HWA-susceptible trees (two from PA-collected seeds and two from MI-collected seeds) were planted in each of eight field plots located throughout the range of HWA in the northeastern USA (Figure 1). Size- and age-matched saplings were provided to cooperators in 15 liter pots for planting at the following locations ordered by latitude in Figure 1: Cornell University, Ithaca, NY (site 1), Arnold Arboretum, Boston, MA (site 2), Yale-Myers Forest, Hamden, CT (site 3), Tiadaghton State Forest, Lycoming County, PA (site 4), New York Botanical Garden, Bronx, NY (site 5), Cunningham Falls State Park, Thurmont, MD (site 6), Kanawha State Forest, Charleston, WV (site 7), and the Mountain Research Station, Waynesville, NC (site 8). All plots were established either within or adjacent to forests 
containing HWA-infested hemlocks. Test saplings were planted randomly in the plots approximately three meters apart. Where needed, plots were enclosed in a deer fence. Following planting, plots were left undisturbed for four years.

Sites

1. Cornell University, Ithaca, NY $(42.6106,-76.4397)$

2. Arnold Arboretum, Boston, MA $(42.2998,-71.1243)$

3. Yale-Myers Forest, Hamden, CT (41.9589, -72.1612)

4. Tiadaghton State Forest, Lycoming County, PA (41.3190, -77.3867)

5. New York Botanical Garden, Bronx, NY $(40.8623,-73.8772)$

6. Cunningham Falls State Park, Thurmont, MD (39.6009, -77.4503)

7. Kanawha State Forest, Charleston, WV (38.3387, -81.6041)

8. Mountain Research Station, Waynesville, NC

(35.4871, -82.9680)

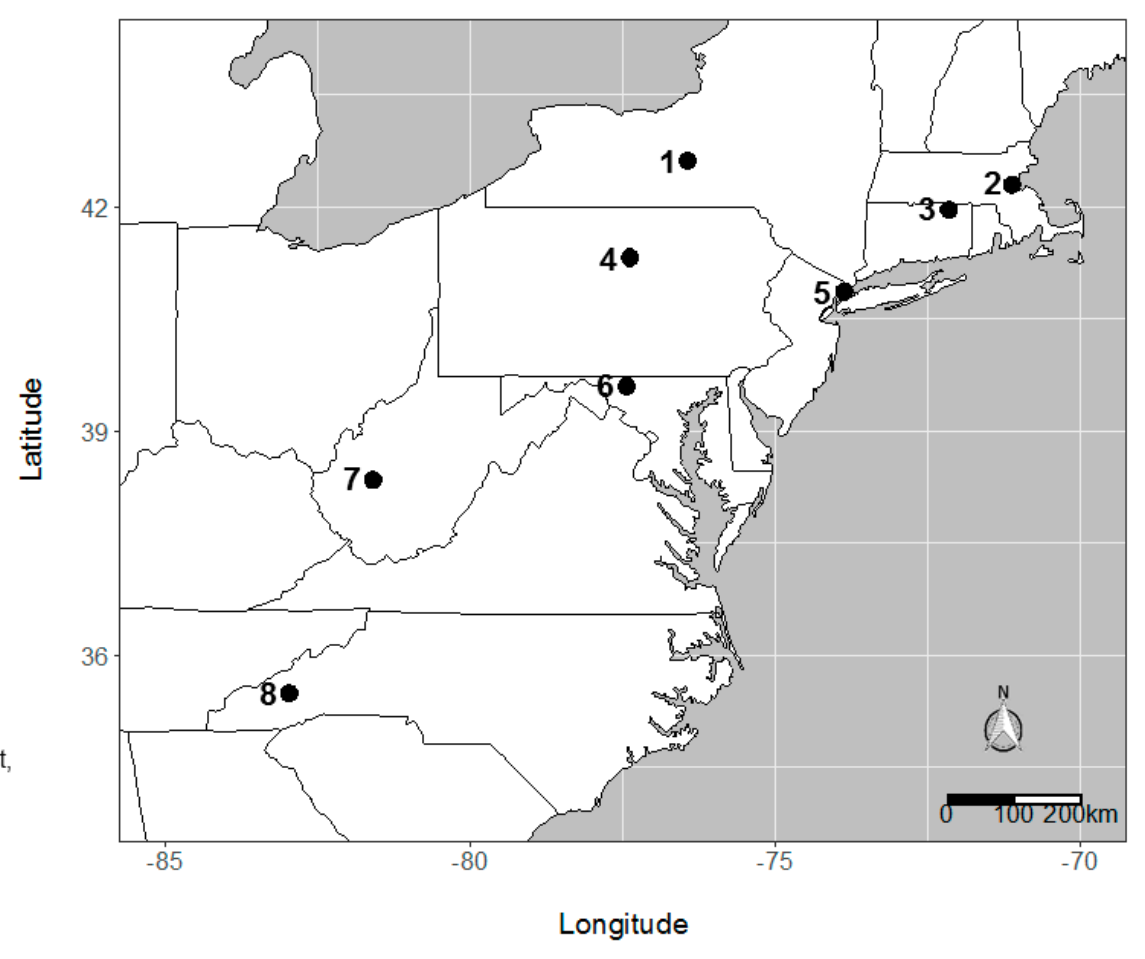

Figure 1. Locations of the eight field plots (numbered by latitude) containing Adelges tsugae (HWA)-resistant and HWA-susceptible eastern hemlock saplings planted in HWA-infested forests.

\subsection{Plot Surveys}

In fall 2019, we returned to each plot and evaluated the saplings for survival and growth. Sapling growth metrics included tree height (total height of stem from ground level to apical growth tip), lateral growth (length of one lateral branch emerging from each of five side branches), drip line (length of longest non-apical terminal branch), trunk diameter at $5 \mathrm{~cm}$ aboveground, and condition ( $\%$ foliage remaining). Condition was quantified visually via a 5 -to- 0 scale: $5=0-20 \%$ foliage loss, $4=21-40 \%$ loss, $3=41-60 \%$ loss, $2=61-80 \%, 1=81-99 \%$ loss, $0=$ dead. To assess HWA and EHS densities, five lateral branches emerging from each of five side branches at varying heights were haphazardly selected on each sapling, and the total number of HWA sistens and EHS on $5 \mathrm{~cm}$ terminal growth were counted.

\subsection{Statistical Analysis}

R software v. 3.5.0 was used for all statistical analyses (R Development Core Team, Vienna, Austria, 2018). Site-level mean survival rate and condition were evaluated among all live and dead trees, using linear mixed models in lme4 [29]; individual identity was considered a random effect. Each model term was tested for significance using Type II Wald chi square tests in car [30]. Growth metrics, HWA densities, and EHS densities were evaluated in a second analysis including only live saplings, using linear mixed models in lme4. Data from all of the test plots was used in the analyses. Significance tests were done using Type II Wald chi square tests in car. Graphics were created in ggplot2 [31]. 


\section{Results}

Ninety-six percent of HWA-resistant hemlocks survived, compared to $48 \%$ of the control plants $\left(t=3.07, X^{2}=9.44, p=0.02\right)$. A comparison of surviving trees found that the HWA-resistant plants were $32 \%$ taller $\left(t=3.25, X^{2}=10.5, p<0.01\right.$; Figure $\left.2 \mathrm{~A}\right)$, put out $18 \%$ more lateral growth $(t=2.40$, $X^{2}=5.80, p=0.01$; Figure $\left.2 B\right)$, had 20\% longer drip lines $\left(t=2.26, X^{2}=5.13, p=0.02\right.$; Figure $\left.2 \mathrm{C}\right)$, and were in $58 \%$ better condition $\left(t=3.87, X^{2}=14.9, p<0.01\right.$; Figure 2D) than the control plants. There were, however, no significant between-treatment differences in stem diameter $\left(t=0.38, X^{2}=0.14\right.$, $p>0.05)$.

A

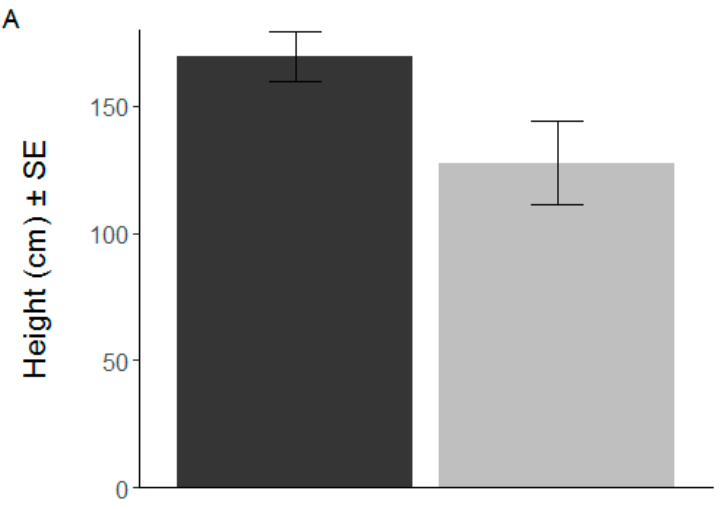

C

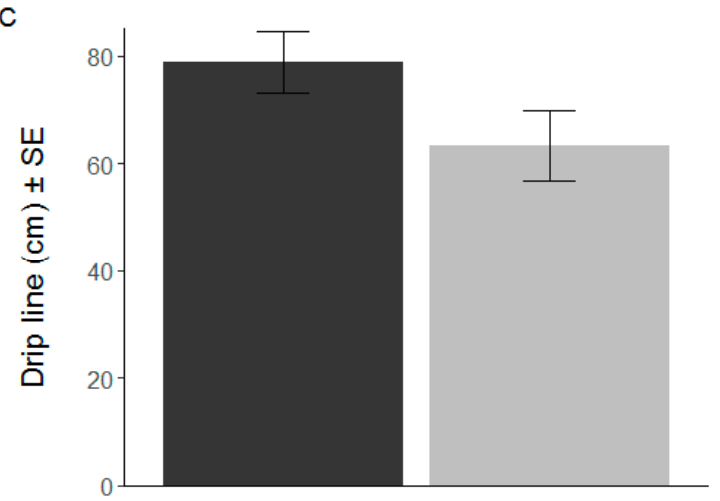

E

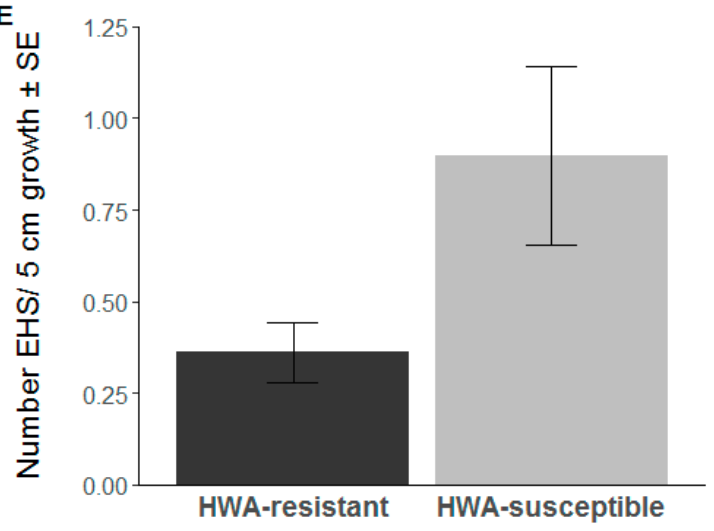

B
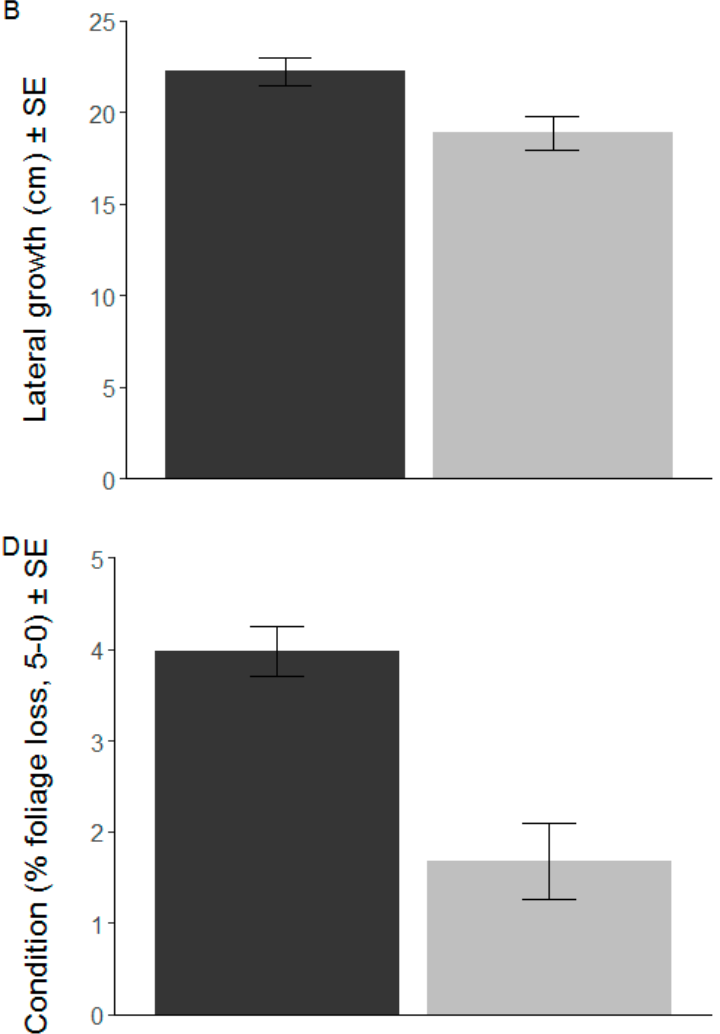

$F$

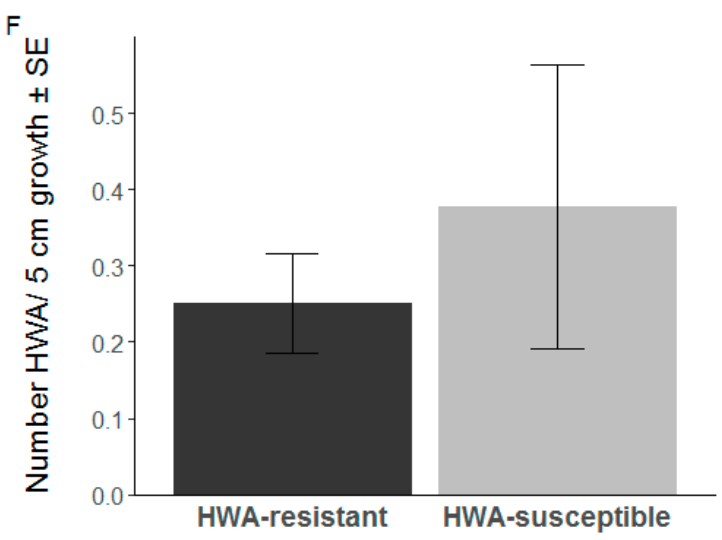

Figure 2. Mean \pm 1 SE height (A), lateral growth (B), drip line (C), condition (D), Fiorinia externa (EHS) densities (E), and HWA densities (F) of HWA-resistant and HWA-susceptible eastern hemlocks grown in HWA-infested field plots for four years.

Trees in all eight plots were found to be infested with EHS. The HWA-resistant hemlocks had EHS densities $60 \%$ lower than those of the controls $\left(t=-2.53, X^{2}=6.44, p<0.01\right.$; Figure 2E). HWA was only found on trees at three out of the eight reforestation plots. The density of HWA on HWA-resistant 
eastern hemlocks was 35\% lower than on HWA-susceptible hemlocks $\left(t=-0.30, X^{2}=0.09, p>0.05\right.$; Figure 2F); the lack of statistical significance likely reflects the small sample size.

\section{Discussion}

We found that HWA-resistant eastern hemlocks outperform HWA-susceptible eastern hemlocks when trees of both types are planted in HWA-infested forests, a result that may prove critical in HWA management. We found that HWA-resistant eastern hemlocks had significantly higher survival, better growth (Figure 2A-C), and retained more foliage (Figure 2D) than HWA-susceptible hemlocks. Biological control and insecticide treatment, the two primary approaches to HWA management, have not been completely effective at mitigating the impact of HWA on eastern hemlock forests [16,32]; as a result, HWA-induced hemlock mortality has severely affected ecosystem dynamics in eastern USA forests. Eastern hemlocks support critical habitat for unique vertebrate and invertebrate communities [33]; dramatic shifts in hydrological regimes, soil nutrient cycling, and understory vegetation, all caused by hemlock decline, may have long-lasting changes that compromise these areas [34]. While additional studies with more replication and detailed monitoring are necessary in order to confirm the result, the fact that HWA-resistant eastern hemlocks grown in HWA-infested forest plots did better than HWA-susceptible trees suggests that HWA-resistant hemlocks should be considered for inclusion in future reforestation efforts.

While the difference in survival and condition was striking, the observed variation in pest densities is equally important. HWA-resistant eastern hemlocks supported $60 \%$ lower EHS densities (Figure 2E) and 35\% lower HWA densities (Figure 2F) than HWA-susceptible trees. These differences may be a result of the higher terpene concentrations in the twigs and needles of the HWA-resistant trees, clonal propagules of the same trees tested elsewhere [24]. Plants respond to stylet-feeding insects via an array of metabolic changes [35], and terpene accumulation is a primary chemical defense of conifers against herbivory [36]. There is strong circumstantial evidence that terpenes affect HWA resistance: the terpene profiles of HWA-resistant Tsuga species differ substantially from those of HWA-susceptible species [18]. Increased terpene concentrations in both eastern hemlock and the Japanese species T. sieboldii are also linked to decreased EHS fecundity [37]. Regardless of mechanism, lower densities of sap-feeding herbivores may also indirectly provide protection against other consumers. Results of field and laboratory research indicate that gypsy moth (Lymantria dispar) and hemlock looper (Lambdina fiscellaria) preferentially consume and have higher fitness on HWA-infested eastern hemlocks [38,39]. Although we did not assess folivore densities, outplantings of HWA-resistant hemlocks may thus also be more likely to survive outbreaks of other pest species.

As with any experiment, there are several caveats that should be mentioned. First, while we made sure that our HWA-resistant and HWA-susceptible hemlock saplings were healthy and grown under similar conditions, and also attempted to match all experimental plants in terms of size and age, we did not record pre-experiment data on plant height or other variables. Without these data, we cannot be certain that variation in initial plant height or dripline did not contribute to current treatment-level differences in these variables. Were this the case, however, we would also have expected to find significant differences in trunk diameter; the fact that HWA-resistant and HWA-susceptible trees did not differ in this variable suggests that any initial between-treatment variation, if present, was minimal. Second it is also important to remember that we were unable to distinguish between the impacts of HWA and EHS on plant growth. While this was a drawback, there is abundant research demonstrating that the impact of EHS on hemlock health is minimal compared to that of HWA $[25,26,40,41]$.

Finally, the absence of monitoring between the 2015 start of the experiment and our 2019 resurvey means that we cannot definitively link increased mortality of HWA-susceptible trees to higher pest densities. While we lacked the funding necessary to conduct such surveys, the lower pest densities and higher survival of HWA-resistant hemlocks are nonetheless consistent with herbivore-driven tree mortality. We also cannot assess the contributions of other environmental stressors (drought, cold, etc.) on our results. Finally, the relatively low number of trees planted at each site (eight 
HWA-resistant and four HWA-susceptible saplings) prevented us from conducting detailed site-level analyses. This limitation means that our work is most appropriately viewed as a 'proof of concept' experiment highlighting the need for future research exploring how HWA-resistant eastern hemlocks might best be integrated into existing HWA management efforts.

Prior to the accidental introduction of HWA, eastern hemlock was one of the most abundant, long-lived, and ecologically significant trees in the eastern USA [42]. Hemlock-dominated forests were characterized by deep shade, acidic and slowly decomposing soil, and a cool microclimate, which together created unique and critical habitat for many terrestrial and aquatic species [34,42]. Unfortunately, neither biological control or insecticide treatments have effectively protected hemlock from HWA [16,32] or prevented the spread of this pest: HWA was recently detected for the first time in western Michigan and has spread north into Nova Scotia [43]. This has resulted in the widespread loss of hemlock, with more than a 60\% decrease in total hemlock basal area since 1997 in New England alone [44]. This loss, in combination with the virtual absence of hemlock regeneration in HWA-infested areas [45], has drastically changed native forest communities. Hemlock-associated forests are now characterized, for instance, by novel understory vegetation communities [46], and significantly reduced soil moisture and $\mathrm{C}: \mathrm{N}$ ratios [34].

\section{Conclusions}

HWA-resistant eastern hemlocks outperformed HWA-susceptible eastern hemlocks when trees of both types are planted in HWA-infested forests, a result that may prove critical in HWA management. These findings suggest that HWA-resistant eastern hemlocks may, by their higher survival and lower pest densities, play a role in restoring hemlock-associated forest dynamics. These findings, in combination with previous work on the HWA-resistant trees we used, provide a strong argument for additional research exploring the identification, characterization, and use of HWA-resistant eastern hemlocks in current and future reforestation efforts.

Author Contributions: Conceptualization, I.G.K., R.A.C. and E.L.P.; Methodology, I.G.K., R.A.C. and E.L.P.; Formal Analysis, I.G.K., C.M.R. and E.L.P.; Investigation, I.G.K., G.G., A.R., C.M.R., R.A.C. and E.L.P.; Resources, R.A.C. and E.L.P.; Data Curation, I.G.K.; Writing-Original Draft Preparation, I.G.K., G.G., A.R., C.M.R., R.A.C. and E.L.P.; Writing-Review and Editing, I.G.K., G.G., A.R., C.M.R., R.A.C. and E.L.P.; Visualization, I.G.K..; Supervision, R.C. and E.L.P.; Project Administration, I.G.K., R.A.C. and E.L.P.; Funding Acquisition, R.A.C. and E.L.P. All authors have read and agreed to the published version of the manuscript.

Funding: Support for IGK and other funding for this work was provided by PA Dept. of Conservation and Natural Resources DCNR 2016-001-HWA-URI and 2018-001-HWA-URI, COLCOM Foundation \#20015270, USDA McIntire-Stennis RI0017-MS979, and US Forest Service 15-CA-11420004-133.

Acknowledgments: This work would not have been possible without the support of Mark Mayer and Rosa Yoo (NJ Dept. of Agriculture), Don Eggen and Mark Faulkenberry (PA Dept. of Conservation and Natural Resources), and Noel Schneeberger (US Forest Service). The manuscript benefitted greatly from the comments of three anonymous reviewers.

Conflicts of Interest: The authors declare no conflict of interest.

\section{References}

1. Sharma, H.; Ortiz, R. Host plant resistance to insects: An eco-friendly approach for pest management and environment conservation. J. Environ. Biol. 2002, 23, 111-136. [PubMed]

2. Schlarbaum, S.E.; Hebard, F.; Spaine, P.C.; Kamalay, J.C. Three American tragedies: Chestnut blight, butternut canker, and Dutch elm disease. In Exotic Pests of Eastern Forests Conference Proceedings; Britton Kerry, O., Ed.; US Forest Service: Washington, DC, USA; Tennessee Exotic Pest Plant Council: Oak Ridge, TN, USA, 1997; pp. $45-54$.

3. Karnosky, D.F. Dutch elm disease: A review of the history, environmental implications, control, and research needs. Environ. Conserv. 1979, 6, 311-322. [CrossRef]

4. Townsend, A.; Bentz, S.; Douglass, L. Evaluation of 19 American elm clones for tolerance to Dutch elm disease. J. Environ. Hortic. 2005, 23, 21-24. 
5. Knight, K.S.; Slavicek, J.M.; Kappler, R.; Pisarczyk, E.; Wiggin, B.; Menard, K. Using Dutch elm disease-tolerant elm to restore flood plains impacted by emerald ash borer. In Proceedings of the Fourth International Workshop on the Genetics of Host-Parasite Interactions in Forestry: Disease and Insect Resistance in Forest Trees, Eugene, OR, USA, 31 July-1 August 2011; Pacific Southwest Research Station: Albany, CA, USA; Forest Service: Washington, DC, USA; US Department of Agriculture: Washington, DC, USA, 2012; pp. 317-323.

6. Paillet, F.L. Chestnut: History and ecology of a transformed species. J. Biogeogr. 2002, 29, 1517-1530. [CrossRef]

7. Milgroom, M.G.; Cortesi, P. Biological control of chestnut blight with hypovirulence: A critical analysis. Annu. Rev. Phytopathol. 2004, 42, 311-338. [CrossRef]

8. Jacobs, D.F.; Dalgleish, H.J.; Nelson, C.D. A conceptual framework for restoration of threatened plants: The effective model of american chestnut (Castanea dentata) reintroduction. New Phytol. 2013, 197, $378-393$. [CrossRef]

9. Cipollini, M.; Dingley, N.R.; Felch, P.; Maddox, C. Evaluation of phenotypic traits and blight-resistance in an American chestnut backcross orchard in Georgia. Glob. Ecol. Conserv. 2017, 10, 1-8. [CrossRef]

10. Knight, K.S.; Haugen, L.M.; Pinchot, C.C.; Schaberg, P.G.; Slavicek, J.M. American elm (Ulmus americana) in restoration plantings: A review. In Proceedings of the American Elm Restoration Workshop 2016, Lewis Center, OH, USA, 25-27 October 2016; US Department of Agriculture: Washington, DC, USA; Forest Service: Washington, DC, USA; Northern Research Station: Newtown Square, PA, USA, 2017; pp. 133-140.

11. Oten, K.L.; Merkle, S.A.; Jetton, R.M.; Smith, B.C.; Talley, M.E.; Hain, F.P. Understanding and developing resistance in hemlocks to the hemlock woolly adelgid. Southeast. Nat. 2014, 13, 147-168.

12. Hanover, J.W. Physiology of tree resistance to insects. Annu. Rev. Entomol. 1975, 20, 75-95. [CrossRef]

13. Showalter, D.N.; Raffa, K.F.; Sniezko, R.A.; Herms, D.A.; Liebhold, A.M.; Smith, J.A.; Bonello, P. Strategic development of tree resistance against forest pathogen and insect invasions in defense-free space. Front. Ecol. Evol. 2018, 6, 124. [CrossRef]

14. Havill, N.P.; Montgomery, M.E.; Yu, G.; Shiyake, S.; Caccone, A. Mitochondrial DNA from hemlock woolly adelgid (hemiptera: Adelgidae) suggests cryptic speciation and pinpoints the source of the introduction to Eastern North America. Ann. Entomol. Soc. Am. 2006, 99, 195-203. [CrossRef]

15. Ellison, A.; Orwig, D.A.; Fitzpatrick, M.; Preisser, E.L. The past, present, and future of the hemlock woolly adelgid (Adelges tsugae) and its ecological interactions with eastern hemlock (Tsuga canadensis) forests. Insects 2018, 9, 172. [CrossRef] [PubMed]

16. Sumpter, K.L.; McAvoy, T.J.; Brewster, C.C.; Mayfield, A.E.; Salom, S.M. Assessing an integrated biological and chemical control strategy for managing hemlock woolly adelgid in southern Appalachian forests. For. Ecol. Manag. 2018, 411, 12-19. [CrossRef]

17. Lagalante, A.F.; Montgomery, M.E.; Calvosa, F.C.; Mirzabeigi, M.N. Characterization of terpenoid volatiles from cultivars of eastern hemlock (Tsuga canadensis). J. Agric. Food Chem. 2007, 55, 10850. [CrossRef]

18. Lagalante, A.F.; Montgomery, M.E. Analysis of terpenoids from hemlock (Tsuga) species by solid-phase microextraction/gas chromatography/ion-trap mass spectrometry. J. Agric. Food Chem. 2003, 51, 2115-2120. [CrossRef]

19. Del Tredici, P.; Kitajima, A. Introduction and cultivation of Chinese hemlock (Tsuga chinensis) and its resistance to hemlock woolly adelgid (Adelges tsugae). Arboric. Urban For. 2004, 30, 282.

20. Hoover, B.K.; Bates, R.M.; Sellmer, J.C.; Hoover, G.A. Challenging Chinese hemlock (Tsuga chinensis) with hemlock woolly adelgid (Adelges tsugae) ovisacs. Arboric. Urban For. 2009, 35, 1-4.

21. Montgomery, M.E.; Bentz, S.E.; Olsen, R.T. Evaluation of hemlock (Tsuga) species and hybrids for resistance to Adelges tsugae (hemiptera: Adelgidae) using artificial infestation. J. Econ. Entomol. 2009, 102, 1247-1254. [CrossRef]

22. Bentz, S.; Riedel, L.G.; Pooler, M.R.; Townsend, A. Hybridization and self-compatibility in controlled pollinations of eastern north American and Asian hemlock (Tsuga) species. J. Arboric. 2002, 28, 200-205.

23. Ingwell, L.L.; Preisser, E.L. Using citizen science programs to identify host resistance in pest-invaded forests. Conserv. Biol. 2011, 25, 182-188. [CrossRef] 
24. McKenzie, E.A.; Elkinton, J.S.; Casagrande, R.A.; Preisser, E.L.; Mayer, M. Terpene chemistry of eastern hemlocks resistant to hemlock woolly adelgid. J. Chem. Ecol. 2014, 40, 1003-1012. [CrossRef] [PubMed]

25. Miller-Pierce, M.; Orwig, D.; Preisser, E. Effects of hemlock woolly adelgid and elongate hemlock scale on eastern hemlock growth and foliar chemistry. Environ. Entomol. 2010, 39, 513-519. [CrossRef] [PubMed]

26. Wilson, C.M.; Schaeffer, R.N.; Hickin, M.L.; Rigsby, C.M.; Sommi, A.F.; Thornber, C.S.; Orians, C.M.; Preisser, E.L. Chronic impacts of invasive herbivores on a foundational forest species: A whole-tree perspective. Ecology 2018, 99, 1783-1791. [CrossRef] [PubMed]

27. Caswell, T.; Casagrande, R.; Maynard, B.; Preisser, E.L. Production and evaluation of hemlocks potentially resistant to the hemlock woolly adelgid. In Proceedings of the Fourth Symposium on Hemlock Woolly Adelgid in the Eastern United States, Hartford, CT, USA, 12-14 February 2008; Onken, B., Reardon, R., Eds.; Forest Health Technology Enterprise Team, Forest Service: Washington, DC, USA, 2008; pp. 124-134.

28. Joseph, S.V.; Kristine Braman, S.; Quick, J.; Hanula, J.L. The range and response of neonicotinoids on hemlock woolly adelgid, Adelges tsugae (hemiptera: Adelgidae). J. Environ. Hortic. 2011, 29, 197-204.

29. Bates, D.; Mächler, M.; Bolker, B.; Walker, S. Fitting linear mixed-effects models using lme4. J. Stat. Softw. 2015, 1, 1-48.

30. Fox, J.; Weisberg, S. Multivar. In An R Companion to Applied Regression; SAGE Publications: Thousand Oaks, CA, USA, 2011.

31. Wickham, H. Ggplot2: Elegant Graphics for Data Analysis; Springer: Berlin, Germany, 2016.

32. Limbu, S.; Keena, M.; Whitmore, M. Hemlock woolly adelgid (hemiptera: Adelgidae): A non-native pest of hemlocks in eastern North America. J. Integr. Pest. Manag. 2018, 9, 27. [CrossRef]

33. Ellison, A.M.; Barker-Plotkin, A.A.; Foster, D.R.; Orwig, D.A. Experimentally testing the role of foundation species in forests: The Harvard forest hemlock removal experiment. Methods Ecol. Evol. 2010, 1, 168-179. [CrossRef]

34. Orwig, D.A.; Cobb, R.C.; D'Amato, A.W.; Kizlinski, M.L.; Foster, D.R. Multi-Year ecosystem response to hemlock woolly adelgid infestation in Southern New England forests. Can. J. For. Res. 2008, 38, 834-843. [CrossRef]

35. Howe, G.A.; Jander, G. Plant immunity to insect herbivores. Annu. Rev. Plant Biol. 2008, 59, 41-66. [CrossRef]

36. Mumm, R.; Hilker, M. Direct and indirect chemical defence of pine against folivorous insects. Trends Plant Sci. 2006, 11, 351-358. [CrossRef]

37. McClure, M.S.; Hare, J.D. Foliar terpenoids in Tsuga species and the fecundity of scale insects. Oecologia 1984, 63, 185-193. [CrossRef]

38. Kinahan, I.G.; Baranowski, A.K.; Whitney, E.R.; Savage, S.K.; Rigsby, C.M.; Shoemaker, E.E.; Orians, C.M.; Preisser, E.L. Facilitation between invasive herbivores: Hemlock woolly adelgid increases gypsy moth preference for and performance on eastern hemlock. Ecol. Entomol. 2020. [CrossRef]

39. Wilson, C.M.; Vendettuoli, J.F.; Orwig, D.A.; Preisser, E.L. Impact of an invasive insect and plant defense on a native forest defoliator. Insects 2016, 7, 45. [CrossRef] [PubMed]

40. Gonda-King, L.; Radville, L.; Preisser, E. False ring formation in eastern hemlock branches: Impacts of hemlock woolly adelgid and elongate hemlock scale. Environ. Entomol. 2012, 41, 523-531. [CrossRef] [PubMed]

41. Soltis, N.E.; Gómez, S.; Gonda-King, L.; Preisser, E.L.; Orians, C.M. Contrasting effects of two exotic invasive hemipterans on whole-plant resource allocation in a declining conifer. Entomol. Exp. Appl. 2015, 157, 86-97. [CrossRef]

42. Ellison, A.M.; Bank, M.S.; Clinton, B.D.; Colburn, E.A.; Elliott, K.; Ford, C.R.; Foster, D.R.; Kloeppel, B.D.; Knoepp, J.D.; Lovett, G.M. Loss of foundation species: Consequences for the structure and dynamics of forested ecosystems. Front. Ecol. Environ. 2005, 3, 479-486. [CrossRef]

43. USFS. Forest Health Protection-Hemlock Woolly Adelgid Distribution Map. Available online: http: //na.fs.fed.us/fhp/hwa/maps/2011.pdf (accessed on 4 March 2020).

44. Gómez, S.; Gonda-King, L.; Orians, C.; Orwig, D.; Panko, R.; Radville, L.; Soltis, N.; Thornber, C.; Preisser, E. Interactions between invasive herbivores and their long-term impact on New England hemlock forests. Biol. Invasions 2015, 17, 661-673. [CrossRef] 
45. Preisser, E.L.; Miller-Pierce, M.R.; Vansant, J.; Orwig, D.A. Eastern hemlock (Tsuga canadensis) regeneration in the presence of hemlock woolly adelgid (Adelges tsugae) and elongate hemlock scale (Fiorinia externa). Can. J. For. Res. 2011, 41, 2433-2439. [CrossRef]

46. Ingwell, L.L.; Miller-Pierce, M.; Trotter, R.T., III; Preisser, E.L. Vegetation and invertebrate community response to eastern hemlock decline in Southern New England. Northeast. Nat. 2012, 19, 541-558. [CrossRef] 